УДК 616.89-008.1:616.89-008.48-024-022.2:355.211.1(571.16)

Для цитирования: Бохан Н.А., Евсеев В.Д., Мандель А.И. Структура и распространенность психических и поведенческих расстройств у лиц призывного возраста в Томской области в 2016-2018 гг. Сибирский вестник психиатрии и наркологии. 2019; 4 (105): 26-33. https://doi.org/10.26617/1810-3111-2019-4(105)-26-33

\title{
Структура и распространенность психических и поведенческих расстройств у лиц призывного возраста в Томской области в 2016-2018 гr.
}

\author{
Бохан Н.А. ${ }^{1,2}$, Евсеев В.Д. ${ }^{1,3}$, Мандель А.И. ${ }^{1}$ \\ ${ }^{1}$ Научно-исследовательский институт психического здоровья, Томский национальный исследовательский \\ медицинский центр Российской академии наук (НИИ психического здоровья Томский НИМЦ) \\ Россия, 634014, Томск, ул. Алеутская, 4 \\ ${ }^{2}$ Сибирский государственный медицинский университет \\ Россия, 634050, Томск, Московский тракт, 2 \\ 3 Лоскутовская районная поликлиника \\ Россия, 634526, Томская область, Томский район, д. Лоскутово, пер. Больничный, д. 1а
}

\section{PEЗЮME}

Цель: изучение распространенности, клинико-психопатологических особенностей психических и поведенческих расстройств у лиц призывного возраста - жителей Томской области в 2016-2018 гг. Обсуждение результатов. В результате обследования 685 призывников, проходивших медицинское освидетельствование в военном комиссариате Томского района Томской области с 2016 по 2018 г., психические расстройства и расстройства поведения выявлены у 93 человек. Структура психических и поведенческих расстройств призывников представлена расстройствами личности и поведения в зрелом возрасте F60-F69 (61,3\%), органическими расстройствами F06 (22,5\%), умственной отсталостью легкой степени F70 (6,5\%), психическими расстройствами и расстройствами поведения вследствие употребления ПАВ F10-F19 (6,5\%). Среди личностной патологии преобладали инфантильное расстройство личности (25 чел.) - 43,8\% и эмоционально неустойчивое расстройство личности (22 чел.) - 38,6\%. С меньшей частотой диагностированы истерическое расстройство (6 чел.), тревожное расстройство личности (3 чел.), расстройство половой идентификации (1 чел.). Зафиксирован высокий уровень призывников с самоповреждающими формами поведения $(26,8 \%)$.

Ключевые слова: призывники, психические расстройства, наркологические расстройства, расстройства личности, органические расстройства, умственная отсталость, алкогольная зависимость, наркомания, несуицидальные самоповреждения, аутоагрессивное поведение.

\section{АКТУАЛЬНОСТЬ ИССЛЕДОВАНИЯ}

Обороноспособность государства относится к основополагающим условиям национальной безопасности и определяется состоянием вооруженных сил и поддержанием боевого потенциала, а также научно-техническими, экономическими и демографическими возможностями страны. Обеспечение национальной безопасности является одной из важнейших функций органов государственной власти и управления. Таким образом, проблема здоровья молодых людей призывного возраста актуальна не только для военных ведомств, ответственных за обороноспособность и безопасность страны, но и для государства в целом. По данным различных авторов, показатели состояния здоровья призывной молодежи продолжают ухудшаться и годность к службе в Вооруженных Силах Российской Федерации в последние годы coставляет от 50 до $70 \%$ в различных регионах РФ [8, 9, 14, 18].
Состояние здоровья призывного контингента в основном определяется поведенческими факторами, в частности такими как употребление наркотических и психотропных веществ, табака и алкоголя, неудовлетворительная структура питания, малоактивный образ жизни $[4,7,13]$. Психические расстройства, как считают многие авторы, являются одной из основных причин освобождения от призыва на военную службу [10].

Количество призывников с установленным психиатрическим расстройством на протяжении последних лет остается примерно на одном уровне и составляет $35-45 \%$ от общего числа направленных на обследование. Большую часть в структуре заболеваемости занимают такие нозологии, как легкая умственная отсталость $(20-30 \%)$ и органические расстройства $(30-40 \%)$, расстройства личности и наркологическая патология [3, 5, 6, 8, 11, 15, 19]. 


\section{ЦЕЛЬ ИССЛЕДОВАНИЯ}

В контексте изложенного целью настоящего исследования явилось изучение распространенности, клинико-психопатологических особенностей психических и поведенческих расстройств, послуживших причиной определения негодности к военной службе лиц призывного возраста в период с 2016 по 2018 г.

\section{МАТЕРИАЛЫ И МЕТОДЫ}

Проведено обследование 685 призывников, проходивших медицинское освидетельствование в военном комиссариате Томского района Томской области с 2016 по 2018 г. Проанализировано 685 личных дел, 77 медицинских заключений (актов медицинского обследования) и 77 медицинских карт амбулаторного больного. Признаки психической патологии выявлены у 93 человек, из них стационарное освидетельствование в ОГБУЗ «Томская областная клиническая психиатрическая больница» и ОГБУЗ «Томский областной наркологический диспансер» прошли 77 призывников. Статистическая обработка данных осуществлялась методами непараметрической статистики с помощью пакета статистических программ «Statistika 6.0», в том числе модулей частотного анализа с использованием критерия хи-квадрат $\left(\chi^{2}\right)$ и сравнения долей. Различия при $\mathrm{p}<0,05$ рассматривались как статистически значимые.

\section{РЕЗУЛЬТАТЫ И ОБСУЖДЕНИЕ}

В результате исследования определена структура психических и поведенческих расстройств призывников, выявленных при проведении военно-врачебной экспертизы (n=93).

По частоте распространенности преобладали расстройства личности и поведения в зрелом возрасте (F60-F69) - 57 чел. (61,3\%). Органические расстройства (F06) встречались в 2,7 раза реже - 21 чел. $(22,5 \%)$. С одинаковой частотой встречаемости зарегистрированы умственная отсталость легкой степени (F70) и психические расстройства и расстройства поведения вследствие употребления ПАВ (F1) в $6,5 \%$ случаев (6 чел.). В единичных случаях в результате освидетельствования диагностированы шизофрения (F20) - у 2 призывников, шизотипическое расстройство (F21) - 1 чел.

Таким образом, расстройства личности занимают первое место среди психической патологии, выявленной в рамках психиатрического освидетельствования. Среди личностной патологии преобладали инфантильное расстройство личности (25 чел.) - 43,8\% и эмоционально неустойчивое расстройство личности (22 чел.) $38,6 \%$, так же диагностированы истерическое расстройство (6 чел.), тревожное расстройство личности (3 чел.), расстройство половой идентификации (1 чел.).

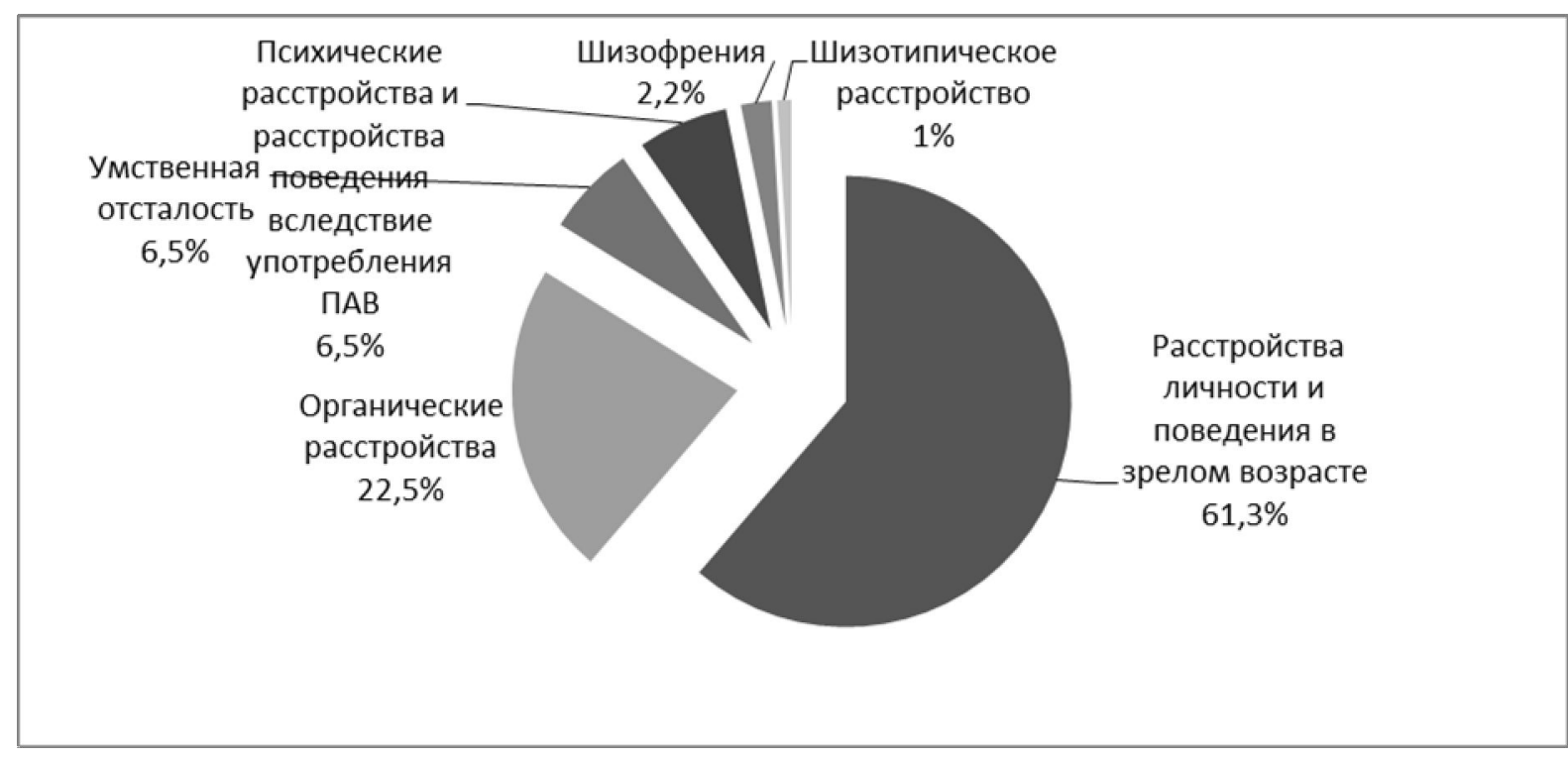

Р и с у н о к 1. Структура психических и поведенческих расстройств у призывников жителей Томской области, выявленных при прохождении военно-врачебной экспертизы

Органическая патология представлена органическим эмоционально лабильным (астеническим) расстройством вследствие различных причин, связанных с соматической и невроло- гической патологией. Все призывники с умственной отсталостью, выявленной в результате экспертизы, имели легкую степень заболевания. Два случая шизофрении представлены 
простым типом течения заболевания. Наркологическая патология диагностирована в рамках расстройств, вызванных одновременным употреблением нескольких наркотических веществ (3 чел.), и алкогольной зависимостью (3 чел.)

На основе анамнестических сведений были выявлены социально-демографические особенности призывников. Средний возраст испытуемых, проходивших стационарное освидетель-

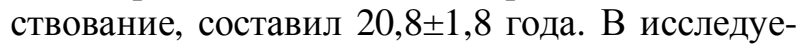
мой группе призывного контингента зафиксирован низкий уровень образования - законченного высшего образования не имел никто; 6,5\% (6 чел.) на момент обследования учились в высших учебных заведениях, более половины призывников $(53,7 \%$ - 50 чел.) имели среднее общее образование (9 классов); 9,7\% (9 чел.) получили среднее полное образование (11 классов); 19,3\% (18 чел.) - среднеспециальное образование; $10,8 \%$ (10 чел.) - незаконченное среднее образование (не закончили 9 классов). Самый низкий уровень образования был выявлен у призывников с умственной отсталостью, инфантильным расстройством личности и органической патологией.

Установлено, что основная масса обследуемых воспитывалась в неблагополучных условиях. По типу гипоопеки в условиях сниженных требований и контроля воспитывались 45,8\% обследованных, из них 50,2\% призывников с расстройствами личности, $18,6 \%$ с умственной отсталостью, $16,5 \%$ с органическими расстройствами, $14,7 \%$ с психическими расстройствами и расстройствами поведения вследствие употребления ПАВ. В бессистемных условиях, для которых характерны частые изменения требований, вызванные изменением фона настроения родителей (с возможным жестоким обращением), воспитывались 18,5\% обследованных, из них основная масса призывного контингента так же приходилась на лиц с личностной патологией $(57,5 \%)$, умственной отсталостью $(15,6 \%)$, наркологическими расстройствами $(16,2 \%)$, органической патологией головного мозга $(10,7 \%)$.

Обнаружено, что более трети обследованных призывников состояли на учете в подразделениях полиции по делам несовершеннолетних $(34,5 \%)$, из них у большинства проходивших освидетельствование призывников выявлены расстройства личности эмоционально неустойчивого круга (в 80,4\% случаев), у 19,6\% призывников диагностировано инфантильное расстройство.
Привлекались к уголовной ответственности более трети $(36,4 \%)$ обследованных, из них у большинства призывников (91\%) было диагностировано эмоционально неустойчивое расстройство личности; с меньшей частотой встречались инфантильное расстройство личности (7\%) и наркологические расстройства (2\%). Из регистра совершенных правонарушений встречались воровство, грабеж, причинение тяжких телесных повреждений, хранение и употребление наркотиков.

Отдельным кластером в военнопсихиатрической экспертизе является аутоагрессивное поведение призывников [8, 12, 16, 17]. Наличие в анамнезе эпизодов аутоагрессивного поведения (несуицидальное самоповреждение) в военно-врачебной психиатрической экспертизе является основанием для направления призывника на обследование в стационар. Согласно B. Walsh [1], несуицидальное самоповреждение - это преднамеренное нанесение себе телесных повреждений, которое не связано с летальным исходом, социально неприемлемое по характеру и реализуемое с целью уменьшить или справиться с психологическим дискомфортом. Эти действия обычно реализуются множеством способов, такими как удары по телу, разрезы или другие повреждения кожи различными предметами, ожоги, создание препятствий для заживления ран [2].

Признаки самоповреждающего поведения зафиксированы более чем в четверти случаев (у 23 призывников - 26,8\%) У большинства лиц призывного возраста с аутоагрессивными паттернами поведения (78,3\% - 18 чел.) выявлено эмоционально неустойчивое расстройство личности, у 2 человек - умственная отсталость легкой степени, у 3 человек - инфантильное расстройство личности. Самоповреждения наносились в возрасте 15-17 лет. 19 призывников совершили самопорезы предплечий (на момент осмотра в виде многочисленных параллельных рубцов), 3 человека в виде способа аутоагрессии выбрали прижигание сигаретой либо спичками, 1 человек осуществил процедуру «шрамирования». Во всех случаях призывники впервые попадали в поле зрения врачапсихиатра только в период прохождения военно-врачебной экспертизы.

Следует отметить, что основная часть психических расстройств $(86,5 \%)$ выявлена на этапе медицинского освидетельствования в воен- 
комате. Ранее призывники психиатрической помощи не получали.

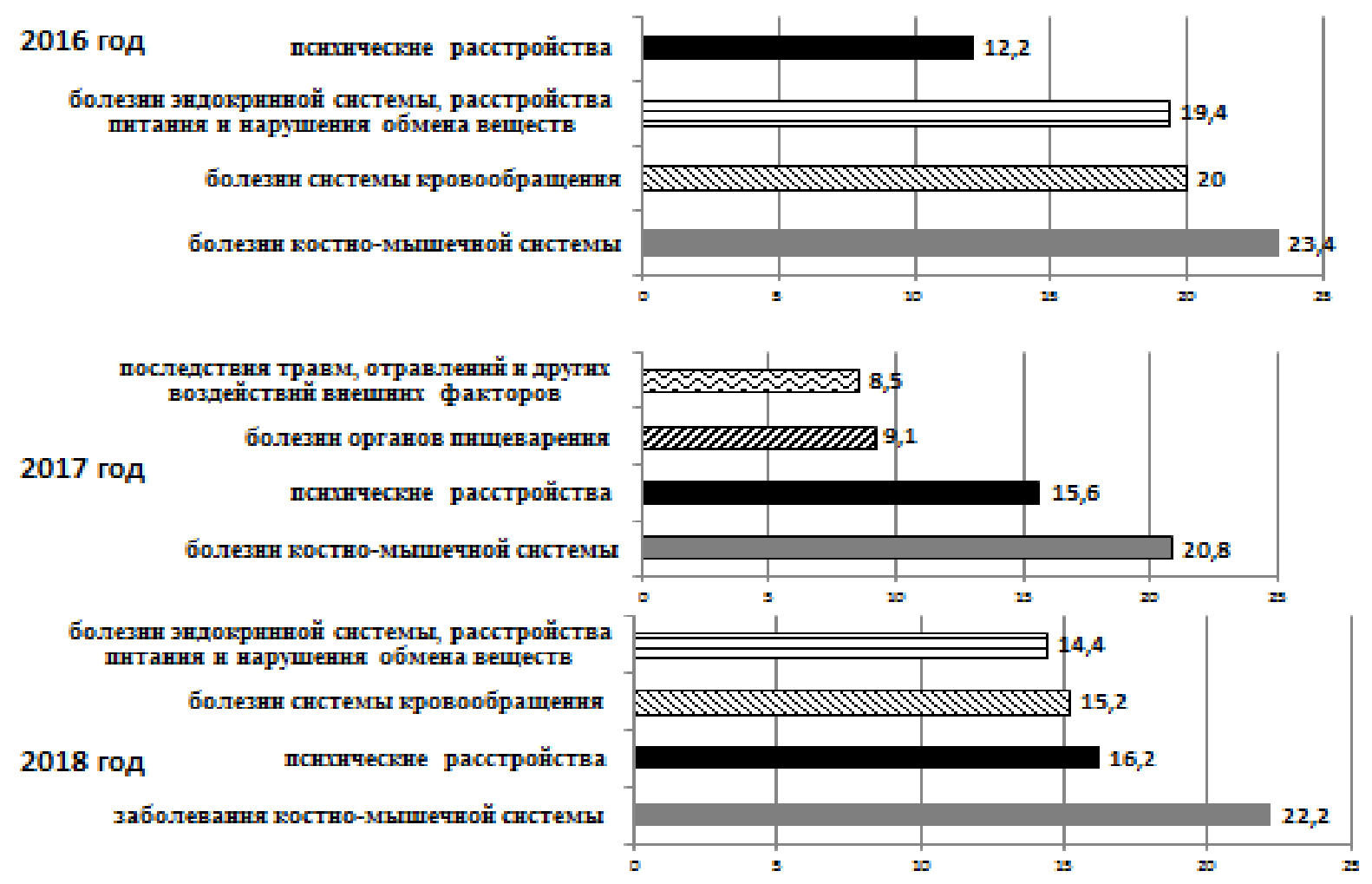

Р и с у н о к 2. Структура основных заболеваний, послуживших причиной освобождения лиц призывного возраста в Томской области в 2016-2018 гг. от призыва на военную службу

На рисунке 2 представлена структура основных заболеваний, послуживших причиной освобождения у проходивших стационарное освидетельствование призывников от призыва на военную службу.

В течение 3 лет показатели негодности призывников к военной службе демонстрируют высокую распространенность психических расстройств, которые в структуре заболеваний, явившихся причинами освобождения призывников от службы в армии, с четвертого места поднимаются на второе; кроме того, меняется структура соматической патологии. В 2016 г. нозологическая структура заболеваний была представлена следующим образом: болезни костно-мышечной системы $(23,4 \%)$, болезни системы кровообращения (20\%), болезни эндокринной системы, расстройства питания и нарушения обмена веществ $(19,4 \%)$, психические расстройства $(12,2 \%)$.

В 2017 г. в структуре патологии, приведшей к освобождению от службы в армии, лидировали болезни костно-мышечной системы (20,8\%), второе место занимали психические расстройства $(15,6 \%)$, затем следовали болезни органов пищеварения $(11,3 \%)$, замыкали четверку ведущих заболеваний последствия травм, отрав- лений и других воздействий внешних факторов $(9,1 \%)$. Затем следовали болезни системы кровообращения $(8,5 \%)$, заболевания эндокринной системы, расстройства питания и нарушения обмена веществ $(8,2 \%)$, нервные болезни $(7,8 \%)$, болезни глаза и его придаточного аппарата $(7,0 \%)$, болезни органов дыхания $(6,2 \%)$. В единичных случаях встречались заболевания кожи и подкожной клетчатки $(4,5 \%)$, патология мочеполовой системы (1\%).

Согласно результатам военно-врачебной экспертизы в 2018 г., заболевания костномышечной системы по-прежнему оставались на первом месте (22,2\%), затем следовали психические расстройства $(16,2 \%)$, при этом процент их оказался выше, чем в предыдущий двухлетний период (12,2\% и 15,6\%). Далее следовали с небольшим отрывом болезни системы кровообращения $(15,2 \%)$ и болезни эндокринной системы, расстройства питания $(14,4 \%)$.

\section{ВЫВОДЫ}

В результате проведенного исследования структуры и распространенности психических и поведенческих расстройств у лиц призывного возраста в Томской области в 2016-2018 гг., послуживших причиной освобождения от призыва на военную службу, выявлен высокий уро- 
вень психической заболеваемости с тенденцией к росту с 2016 по 2018 г.: 12,2\% - 15,6\% $16,2 \%$ соответственно. В структуре психической патологии неизменно преобладали расстройства личности, органическая патология головного мозга и умственная отсталость.

Признаки самоповреждающего поведения зарегистрированы у 23 призывников (26,8\%). У большинства лиц призывного возраста с аутоагрессивными паттернами поведения диагностировано эмоционально неустойчивое расстройство личности $(78,3 \%)$. Наличие в анамнезе эпизодов аутоагрессивного поведения (несуицидальное самоповреждение) при военно-врачебной психиатрической экспертизе является основанием для направления призывника на обследование в стационар. Большинство психических расстройств $(86,5 \%)$ выявлено на этапе медицинского освидетельствования в военкомате. Ранее призывники психиатрической помощи не получали.

\section{КОНФЛИКТ ИНТЕРЕСОВ}

Авторы заявляют об отсутствии возможных конфликтов интересов в связи с публикацией данной статьи.

\section{ИСТОЧНИК ФИНАНСИРОВАНИЯ}

Статья выполнена по основному плану НИР в рамках госзадания (шифр темы: № 0550-20190007).

\section{СООТВЕТСТВИЕ ПРИНЦИПАМ ЭТИКИ}

Работа соответствует этическим стандартам Хельсинской декларации ВМА (протокол заседания локального этического комитета НИИ психического здоровья № 125 от 21 ноября 2019 г., дело № 125/5. 2019).

\section{ЛИТЕРАТУРА}

1. Barent W.W. Treating self-injury: A Practical Guide. Second Edition. New York : Guilford Press, 2014: 413.

2. Saraff P.D., Pepper C.M. Functions, lifetime frequency, and variety of methods of non-suicidal self-injury among college students. Psychiatry Res. 2014 Oct 30; 219(2): 298-304. doi: 10.1016/j.psychres.2014.05.044

3. Агарков А.А., Скороходова Т.Ф., Погорелова Т.В. Факторы риска психических расстройств у подростков допризывного и призывного возрастов. Сибирский вестник психиатрии и наркологии. 2011; 4(67): 61-64.

4. Айзман Р.И., Лебедев А.В., Айзман Н.И., Рубанович В.Б. Методология и практика мониторинга здоровья учащейся молодежи. Журнал научных статей. Здоровье и образование в XXI веке. 2017; 19(5): 73-78.

5. Акимов В.В., Сидорова М.В., Суслина Л.И. Показатели и оценка работы врача психиатра на примере РВК Засвияжского района г. Ульянов- ска с 2014 по 2016 г. Современные аспекты здравоохранения: достижения и перспективы: Материалы 52-й межрегиональной научнопрактической медицинской конференции. Ульяновск, 2017: 361-363.

6. Белогоров С.Б., Долгих В.В., Смирнов Е.Л., Чичкалюк В.А., Атаманюк А.Б., Тунгусов Е.И., Колесникова Е.Н. Здоровье призывников Иркутской области. Сибирский медицинский журнал. 2008; 4: 58-61.

7. Бохан Н.А., Воеводин И.В. Аутодеструктивность в формировании аддиктивных и невротических расстройств: суицидальное и рискованное поведение. Обозрение психиатрии и медицинской психологии им. В.М. Бехтерева. 2016; 1: 59-65.

8. Бохан Н.А., Евсеев В.Д. Мандель А.И. Распространенность психических и наркологических расстройств среди лиц призывного возраста в регионах РФ. Социальная и клиническая психиатрия. 2019; 29 (3); 102-108.

9. Булавин В.В., Кальманов А.С., Панюшин К.А., Бровкин С.Г., Работкин О.С., Житников А.Г. Состояние здоровья подростков, допризывников и призывников и организация мероприятий по его укреплению. Военно-медицинский журнал. 2014; 3: 56-58.

10. Говорин Н.В., Сахаров А.В., Ступина О.П., Кичигина И.В. Психическое здоровье призывного контингента. Чита: Экспресс-издательство, 2011: 204.

11. Евсеев В.Д., Мандель А.И. Распространенность психических и наркологических расстройств среди лиц призывного контингента муниципального образования Томской области. Сибирский вестник психиатрии и наркологии. 2018; 3 (100): 40-45. https://doi.org: 10.26617/1810-31112018-3(100)-40-45

12. Захарова Е.В., Фильштинская Е.Г., Аборина М.В., Мазанкина Е.В. Факторы формирования рискованного поведения молодежи. Тенденциии развития науки и образования. 2019; 52 (1): 70-73.

13. Калабихина И.Е., Бессонова Е.В., Денисова И.А., Калмыкова Н.М., Эченикэ В.Х. Демографический потенциал военного планирования: человеческий капитал военного контингента. Вооружение и экономика. 2018; 2 (44): 58-67.

14. Марков Р.А., Амлаев К.Р. Состояние здоровья юношей призывного и допризывного возраста в России. Астраханский медицинский журнал. 2016; 11(3): 44-52.

15. Петрова Н.В. Состояние психического здоровья юношей допризывного и призывного возраста: автореф. дис. ... к.м.н. Томск, 2004: 20.

16. Сахаров А.В., Говорин Н.В., Ступина О.П., Озорнин А.С., Колчанова Т.Г. Суицидальное поведение среди несовершеннолетних в Забайкальском крае, проблема «групп смерти». Cu- 
бирский вестник психиатрии и наркологии. 2017; 2 (95): 42-47.

17. Таранова Е.И. Семья как фактор, влияющий на формирование аутоагрессивного, суицидального поведения в подростковом возрасте. Научные ведомости БелГУ. Серия: Медицина. Фармация. 2011; 10: 44-49.

18. Ядчук В.Н., Андроненков И.А. Оценка удовлетворенности призывников организацией медицинского обслуживания при подготовке к военной службе. Проблемы социильной гигиены, здравоохранения и истории медиичны. 2011; 5: 16-18.

19. Яценко К.О., Володина Е.Е., Никитошенко Е.Г., Нифанова Ю.А. Проблема дифференциальной диагностики органического расстройства личности и эмоционально неустойчивого расстройства личности у лиц призывного возраста. $\mathrm{Cu}$ бирский вестник психиатрии и наркологии. 2011; 2 (65): 45-46.

Поступила в редакцию 24.09.2019 Утверждена к печати 02.12.2019

Бохан Николай Александрович, академик РАН, д.м.Н., профессор, директор НИИ психического здоровья Томского НИМЦ, руководитель отделения аддиктивных состояний; заведующий кафедрой психиатрии, наркологии и психотерапии.

Евсеев Вячеслав Дмитриевич, к.м.н., старший научный сотрудник отделения аддиктивных состояний НИИ психического здоровья Томского НИМЦ; врач-психиатр ОГБУЗ «Лоскутовская районная поликлиника»; врач, руководящий работой по медицинскому освидетельствованию граждан, подлежащих призыву на военную службу в составе призывной комиссии Томского района Томской области (Распоряжения Губернатора Томской области от 30 марта 2016 г. № 81-p, 22 сентября 2017 г. № 200-p, 25 сентября 2018 г. № 260 -р «О призыве граждан РФ, проживающих на территории Томской области, на военную службу...»).

Мандель Анна Исаевна, д.м.н., профессор, ведущий научный сотрудник отделения аддиктивных состояний НИИ психического здоровья Томского НИМЦ.

Евсеев Вячеслав Дмитриевич, slawix @mail.ru

УДК 616.89-008.1:616.89-008.48-024-022.2:355.211.1(571.16)

For citation: Bokhan N.A., Evseev V.D., Mandel A.I. Structure and prevalence of mental and behavioral disorders in persons of military age in the Tomsk Region in 2016-2018. Siberian Herald of Psychiatry and Addiction Psychiatry. 2019; 4 (105): 26-33. https://doi.org/10.26617/1810-3111-2019-4(105)-26-33

\section{Structure and prevalence of mental and behavioral disorders in persons of military age in the Tomsk Region in 2016-2018 Bokhan N.A. ${ }^{1,2}$, Evseev V.D. ${ }^{1,3}$, Mandel A.I. ${ }^{1}$ \\ ${ }^{I}$ Mental Health Research Institute, Tomsk National Research Medical Center, Russian Academy of Sciences Aleutskaya Street 4, 634014, Tomsk, Russian Federation \\ ${ }^{2}$ Siberian State Medical University \\ Moskovsky Trakt 2, 634050, Tomsk, Russian Federation \\ ${ }^{3}$ Loskutovo District Clinic \\ Bol'nichnyy Lane 1a, 634526, Tomsk Region, Loskutovo Village, Russian Federation}

\section{ABSTRACT}

Objective: to study the prevalence, clinical-psychopathological characteristics of mental and behavioral disorders in persons of military age - residents of the Tomsk Region in 2016-2018. Discussion. As a result of the examination of 685 recruits undergoing a medical examination at the military commissariat of the Tomsk Region from 2016 to 2018, mental disorders and behavioral disorders were detected in 93 individuals. The structure of mental and behavioral disorders of conscripts was represented by disorders of adult personality and behavior F60-F69 (61.3\%), organic disorders F06 (22.5\%), mild mental retardation F70 (6.5\%), Mental and behavioural disorders due to psychoactive substance use F10-F19 (6.5\%). Among personality pathology, immature personality disorder (25 persons) - 43.8\% and emotionally unstable personality disorder ( 22 persons) $-38.6 \%$ prevailed. Histrionic personality disorder (6 persons), anxious personality disorder ( 3 persons), and gender identity disorder (1 person) were diagnosed with lesser frequency. A high level of draftees with self-injurious forms of behavior was recorded $(26.8 \%)$.

Keywords: persons of military age, mental disorders, substance use disorders, personality disorders, organic disorders, mental retardation, alcohol addiction, drug addiction, non-suicidal self-injury, auto-aggressive behavior. 


\section{REFERENCES}

1. Barent W.W. Treating self-injury: A Practical Guide. Second Edition. New York : Guilford Press, 2014: 413.

2. Saraff P.D., Pepper C.M. Functions, lifetime frequency, and variety of methods of non-suicidal self-injury among college students. Psychiatry Res. 2014 Oct 30; 219(2): 298-304. doi: 10.1016/j.psychres.2014.05.044

3. Agarkov A.A., Skorokhodova T.F., PogorelovaT.V. Faktory riska psikhicheskikh rasstroystv u podrostkov doprizyvnogo i prizyvnogo vozrastov [Risk factors of mental disorders in adolescents of preconscription and conscription ages]. Sibirskiy vestnik psikhiatrii $i$ narkologii - Siberian Herald of Psychiatry and Addiction Psychiatry. 2011; 4(67): 61-64 (in Russian).

4. Aizman R.I., Lebedev A.V., Aizman N.I., Rubanovich V.B. Metodologiya i praktika monitoringa zdorov'ya uchashcheysya molodezhi [Methodology and practice of monitoring the health of students]. Zhurnal nauchnyh statej Zdorov'e i obrazovanie $v$ XXI veke - Journal of Scientific Articles Health and Education in the 21st Century. 2017; 19(5): 73-78 (in Russian).

5. Akimov V.V., Sidorova M.V., Suslina L.I. Pokazateli i otsenka raboty vracha psikhiatra na primere RVK Zasviyazhskogo rayona goroda Ul'yanovska s 2014 po 2016 god [Indicators and evaluation of the work of a psychiatrist on the example of RVK Zasviyazhsky district of Ulyanovsk from 2014 to 2016.] Modern aspects of healthcare: achievements and prospects: Materials of the 52nd interregional scientific-practical medical conference. Ulyanovsk, 2017: 361-363 (in Russian).

6. Belogorov S.B., Dolgikh V.V., Smirnov E.L., Chichkalyuk V.A., Atamanyuk A.B., Tungusov E.I., Kolesnikova E.N. Zdorov'ye prizyvnikov Irkutskoy oblasti [Health of recruits in the Irkutsk Region]. Sibirskiy meditsinskiy zhurnal - Siberian Medical Journal. 2008; 4: 58-61 (in Russian).

7. Bokhan N.A., Voevodin I.V. Autodestruktivnost' v formirovanii addiktivnykh i nevroticheskikh rasstroystv: suitsidal'noye i riskovannoye povedeniye [Auto-destructivity in the formation of addictive and neurotic disorders: suicidal and risky behavior]. Obozrenie psihiatrii i medicinskoj psihologii imeni V.M. Bekhtereva - Review of Psychiatry and Medical Psychology named after V.M. Bekhterev. 2016; 1: 59-65 (in Russian).

8. Bokhan N.A., Evseev V.D., Mandel A.I. Rasprostranennost' psikhicheskikh i narkologicheskikh rasstroystv sredi lits prizyvnogo vozrasta $\mathrm{v}$ regionakh RF [Prevalence of mental and narcological disorders among persons of military age in the regions of the Russian Federation]. Social'naya i klinicheskaya psihiatriya - Social and Clinical Psychiatry. 2019; 29 (3); 102-108 (in Russian).
9. Bulavin V.V., Kalmanov A.S., Panyushin K.A., Brovkin S.G., Rabotkin O.S., Zhitnikov A.G. Sostoyaniye zdorov'ya podrostkov, doprizyvnikov i prizyvnikov i organizatsiya meropriyatiy po yego ukrepleniyu [The state of health of adolescents, preconscripts and conscripts and the organization of measures to strengthen it]. Voenno-medicinskij zhurnal - Military Medical Journal. 2014; 3: 56-58 (in Russian).

10. Govorin NV., Sakharov A.V., Stupina O.P., Kichigina I.V. Psikhicheskoye zdorov'ye prizyvnogo kontingenta [Mental health of conscription contingent. Chita: Express Publishing House, 2011: 204 (in Russian).

11. Evseev V.D., Mandel A.I. Rasprostranennost' psikhicheskikh i narkologicheskikh rasstroystv sredi lits prizyvnogo kontingenta munitsipal'nogo obrazovaniya Tomskoy oblasti [Prevalence of mental and narcological disorders among persons of conscription contingent of municipal formation of Tomsk Region]. Sibirskiy vestnik psikhiatrii $i$ narkologii Siberian Herald of Psychiatry and Addiction Psychiatry. 2018; 3 (100): 40-45 (in Russian). https://doi.org/10.26617/1810-3111-2018-3(100)-4045

12. Zakharova E.V., Filshtinskaya E.G., Aborina M.V., Mazankina E.V. Faktory formirovaniya riskovannogo povedeniya molodezhi [Factors of formation of risky behavior of youth]. Tendencii razvitiya nauki i obrazovaniya - Trends in the Development of Science and Education. 2019; 52(1): 70-73 (in Russian).

13. Kalabikhina I.E., Bessonova E.V., Denisova I.A., Kalmykova N.M., Echenike V.H. Demograficheskiy potentsial voyennogo planirovaniya: chelovecheskiy kapital voyennogo kontingenta [Demographic potential of military planning: human capital of the military contingent]. Vooruzhenie $i$ ekonomika - Arms and Economics. 2018; 2 (44): 58-67 (in Russian).

14. Markov R.A., Amlaev K.R. Sostoyaniye zdorov'ya yunoshey prizyvnogo i doprizyvnogo vozrasta $\mathrm{V}$ Rossii [State of health of young men of conscription and pre-conscription age in Russia]. Astrahanskij medicinskij zhurnal - Astrakhan Medical Journal. 2016; 11(3): 44-52 (in Russian).

15. Petrova N.V. Sostoyaniye psikhicheskogo zdorov'ya yunoshey doprizyvnogo i prizyvnogo vozrasta [The state of mental health of young men of preconscription and military age]: dissertation abstract ... PhD. Tomsk, 2004: 20 (in Russian).

16. Sakharov A.V., Govorin N.V., Stupina O.P., Ozornin A.S., Kolchanova T.G. Suitsidal'noye povedeniye sredi nesovershennoletnikh $\mathrm{V}$ Zabaykal'skom kraye, problema «grupp smerti» [Suicidal behavior of children and adolescents in the Trans-Baikal Krai, the problem of "groups of death"]. Sibirskiy vestnik psikhiatrii $i$ narkologii Siberian Herald of Psychiatry and Addiction Psychiatry. 2017; 2 (95): 42-47 (in Russian). 
17. Taranova E.I. Sem'ya kak faktor, vliyayushchiy na formirovaniye autoagressivnogo, suitsidal'nogo povedeniya $\mathrm{v}$ podrostkovom vozraste [Family as a factor influencing the formation of auto-aggressive, suicidal behavior in adolescence]. Nauchnye vedomosti BelGU. Seriya: Medicina. Farmaciya Scientific Statements of Belgorod State University. Series: Medicine. Pharmacy. 2011; 10: 44-49 (in Russian).

18. Yadchuk V.N., Andronikov I.A. Otsenka udovletvorennosti prizyvnikov organizatsiyey meditsinskogo obsluzhivaniya pri podgotovke $\mathrm{k}$ voyennoy sluzhbe [Assessment of recruits ' satisfaction with the organization of medical care in preparation for military service]. Problemy social'noj gigieny, zdravoohraneniya $i$ istorii mediciny - Problems of
Social Hygiene, Health Care and the History of Medicine. 2011; 5: 16-18 (in Russian).

19. Yatsenko K.O., Volodina E.E., Nikitoshenko E.G., Nifanova Yu.A. Problema differentsial'noy diagnostiki organicheskogo rasstroystva lichnosti i emotsional'no neustoychivogo rasstroystva lichnosti u lits prizyvnogo vozrasta [The problem of differential diagnosis of organic personality disorder and emotionally unstable personality disorder in persons of military age]. Sibirskiy vestnik psikhiatrii $i$ narkologii - Siberian Herald of Psychiatry and Addiction Psychiatry. 2011; 2 (65): 45-46 (in Russian).

Received September 24.2019 Accepted December 02.2019

Bokhan Nikolay A., academician of RAS, MD, Prof., Honored Scientist of the Russian Federation, Head of Addictive States Department, director of Mental Health Research Institute, Tomsk National Research Medical Center, Russian Academy of Sciences; Head of the Department of Psychiatry, Addiction Psychiatry and Psychotherapy, Siberian State Medical University, Tomsk, Russian Federation.

Evseev Vyacheslav D., PhD., senior researcher of Addictive States Department, Mental Health Research Institute, Tomsk National Research Medical Center, Russian Academy of Sciences, Tomsk, Russian Federation, psychiatrist, Loskutovo District Clinic; a doctor who supervises the medical examination of citizens subject to conscription for military service as part of the draft commission of the Tomsk Region of the Tomsk Region (Order of the Governor of the Tomsk Region dated March 30, 2016 No. 81-p, September 22, 2017 No. 200-p, September 25 2018 No. $260-p$ "On the draft of citizens of the Russian Federation living in the territory of the Tomsk Region for military service...").

Mandel Anna I., MD, Professor, lead researcher of Addictive States Department, Mental Health Research Institute, Tomsk National Research Medical Center, Russian Academy of Sciences, Tomsk, Russian Federation.

Evseev Vyacheslav D., slawix@mail.ru 